\title{
EVALUATION OF A SIMPLE MANUALY OPERATED PLANTING UNIT SUITABLE FOR SLOPING LANDS
}

\author{
Khater, M. M. I.*
}

\section{ABSTRACT}

The idea to cultivate the grass seeds into the soil by trenches and conserve rain water was identified by using a simple manually operated planting unit to be easy using four sloping lands which were 4.8, 6.6, 8.6 and $10.4 \%$ under experimented area in arid conditions to cultivate Rhodes grass. The laboratory investigation included determination of the rate of seed discharge, uniformity of seed spacing and seed damage during operation. The obtained data revealed that soil moisture content measured from the manually operated planting unit had the highest values during growth season and can be ranked as $4.8 \%>6.6 \%>8.6 \%$ $>10.4 \%$ land slopes. Also, the soil moisture content values after 40 days of planting date were higher than that obtained after 3 days. The highest values of soil moisture content were 25.53 and $36.26 \%$ for manually operated planting unit under $4.8 \%$ land slope treatment after 3 and 40 days of planting date respectively. On the other hand, the yield values revealed that the manually operated planting unit had the highest record. The highest biological yield value was $92.447 \mathrm{Mg} / \mathrm{ha}$ by using manually operated planting unit with land slope of $4.8 \%$. The lowest biological yield value was $48.059 \mathrm{Mg} / \mathrm{ha}$ by using of hand labor planting method with land slope of $10.4 \%$ treatment.

Keywords: manually operated planting unit, soil moisture content, seed germination, yield.

\section{INTRODUCTION}

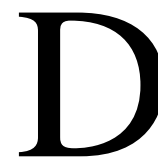
rought has been identified as a major environmental problem in some farming areas and valleys, specially in the North Western Coast of Egypt. Planting into soils under the conditions of sloping lands need to be identifying. Adisa (1980) designed and constructed a manually operated flute planter/fertilizer distributor which was found to be $94 \%$ efficient in seed spacing but could not be used on the ridged seed bed and requires quite some effort and time to change seed drill size and seed spacing.

*Soil Conservation Department, Desert Research Center, Cairo, Egypt 
Simulations showed that an automatic propelled punch wheel with positive slip was necessary to aid in clearing of the punch tips. This same idea has been suggested by Srivastava and Anibal (1981). Another approach to planting uses a punch planter, which only penetrates the soil to deposit seed Adekoya and Buchele, (1987). A punch planter is conceptually ideal for no-till planting because it disturbs a minimal amount of soil and is useful for crops sensitive to precision spacing. Punch planting is an old technique that still persists today in some countries, especially when manual devices are used. A comprehensive review by Morrison and Allen (1987) discussed performance characteristics required of planters and the challenges that must be addressed in conservation tillage systems. There are many accessories and attachments readily available for enhancing standard planters for no-till conditions. Rogers and Baron (1987) designed a similar manual planter for small seeds using an air seed meter. The system had problems because many of the seeds were dropped on the soil surface. after designing and testing a seed planter for no-till. Also Braide and Njidda (1989) developed a combined jab planter which was found to be $73.4 \%$ efficient and was three times faster than manual planting with hoes and cutlass. Shaw and Kromer (1989) observed operational difficulties with a machine that used trenches with cam activated doors, especially when operating in wet soil or with a high accumulation of residue. Kachman and Smith (1995) tested and compared the most widely used measures; mean, standard deviation, miss index and precision. Those measures were based on the standards limitations and gave a good indication of the spacing distribution. Molin and D' Agostin (1996) developed a rolling planter for stony conditions, using 12 spades radially arranged with cam activated doors and a plate seed meter. Performance evaluation showed important improvement in the planting operation with reduction in human effort, more accurate stands and high field capacity. Wohab (2003) developed a minimum tillage planter with effective field capacity of 0.1 ha/hr. The planter saved $35 \%$ time and $27 \%$ cost when compared to traditional methods. Bamgboye and Mofolasayo (2006) tested a manually operated two row okra planter developed from locally available materials. The planter had a field capacity of $0.36 \mathrm{ha} / \mathrm{h}$ with a field 
efficiency close to $72 \%$. The laboratory tests gave better spacing results than under field tests due to clogging of seeds and germination failure. Robert, et al., (2009) reported that no-till planters and drills must be able to cut and handle residue, penetrate the soil to the proper seeding bed, and establish good seed soil contact. In sloping lands moist soils, which may be wet in specific seasons need to provide an ideal seed germination environment, such conditions can make it difficult to conserve water retention. In contrast, hard and dry conditions may also prevail. This is especially common when water evaporated during the hot, dry months of June to August. A disc type maize seeder developed which is simple in design and can be handily operated with ease and comfort (Rolando et al, 2011). It requires a pre-established furrow and after the falling of seed they are covered by soil. This is a labor intensive and time consuming process. Even in areas where the soil water retention is a limitation, farmers still have problems dealing with sloping land conditions, indicating that research for planting needs to be continued. The investigated manual planter is an alternative concept for no-till as it rolls over the soil surface and to overcome the un-regularity of seed spacing. Therefore, this research work aimed to:

1- Evaluate the performance of a simple manually operated planting unit compared with labor hand planting under 4 different slopes to develop desired soil structure for a seedbed.

2- Establish specific surface configurations of planting for water retention and seeds distribution.

3- Determine the factors that realizes the best operation condition

\section{MATERIALS AND METHODS}

Field experiments were carried out in El Rawashed valley (Maged valley), West Marsa Matrouh; Matrouh Governorate, Egypt. The experimental site was located at latitude of $31^{\circ} 20^{\prime} 05^{\prime \prime} \mathrm{N}$ and longitude of $27^{\circ} 06^{\prime} 53^{\prime \prime} \mathrm{E}$. The idea was depending on putting the grass seeds into the soil by soil preparation and conserve rain water under sloping lands in arid and semi arid conditions. Tests were carried out on a simple manually hand-pushed rolling planting unit as shown in figure (1). The soil of the experimental farm was classified as sandy loam $(77.12 \%$ sand, 
$11.28 \%$ silt and $11.60 \%$ clay). Particle size distribution of soil was determined according to Kulte, (1986).

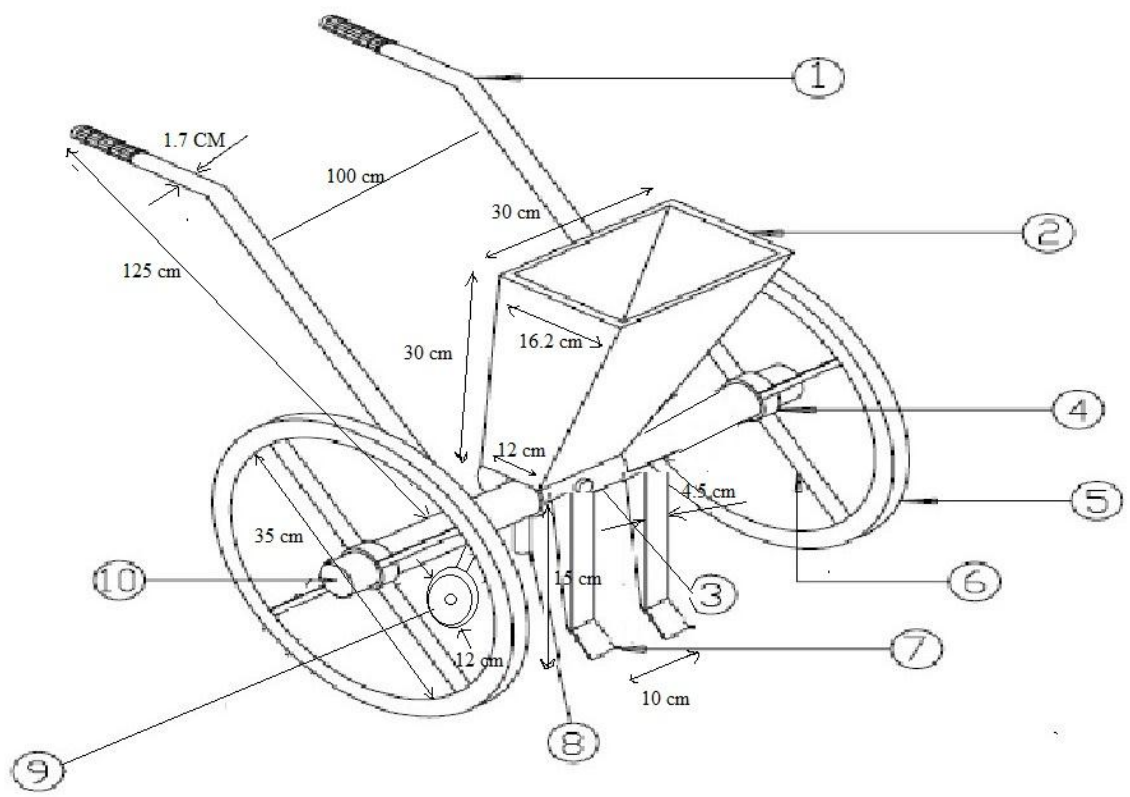

Key of figure 1

1. Handle, 2. Seed hopper, 3. Metering disc, 4. Wheel , 5. Drive/transport wheel, 6. Strokes,7. Furrow opener, 8. Seed tube, 9. Pressing wheel and 10. Axle.

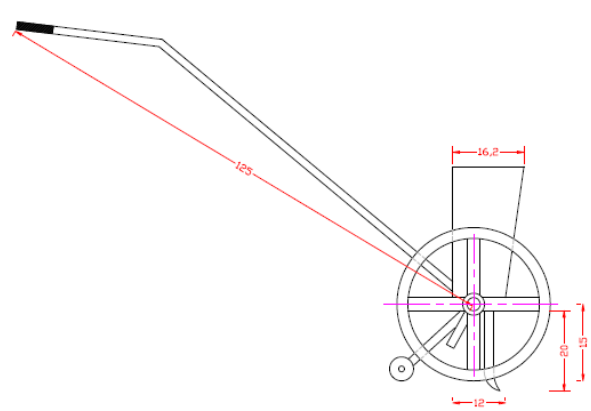

S.View

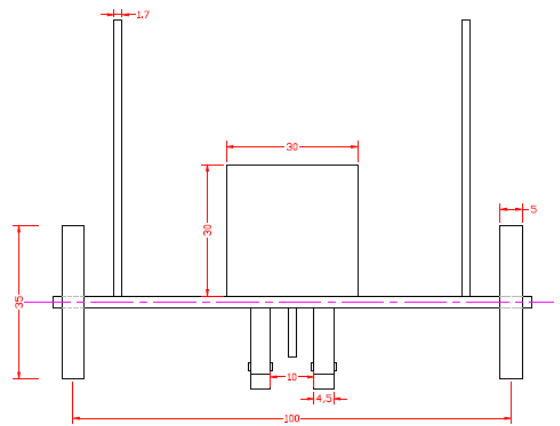

Elev.

Fig. (1): Manually operated planting unit

\section{Experimental procedure:}

The experiments aimed to compare the effect of manually operated planting unit and hand labor planting treatments on water retention and 
seeds distribution as well as seed germination and yield of Rhodes grass (Chloris gayana) which was planted through the second week of November 2014. Field experiments were conducted at different land slopes of 4.8, 6.6, 8.6 and 10.4\% (2 $2^{\circ} 52^{\prime} 08^{\prime \prime \prime}, 3^{\circ} 57^{\prime} 06^{\prime \prime \prime}, 5^{\circ} 09^{\prime} 06^{\prime \prime \prime}$ and $6^{\circ} 14^{\prime} 04^{\prime \prime \prime)}$. Land slope was measured by using a digital clinometer. The digital display gives a reading that shown as a percent and degrees, or as a digital bubble.

\section{Description of the planter:}

The simple manually operated planter unit (figure1) was consisted of: handles, feed hopper, metering disc, transported wheel, furrow opening, seed tube and furrow covering device.

1- Handles: The handles were of two mild steel pipes of $1.7 \mathrm{~cm}$ internal diameter and $125 \mathrm{~cm}$ length for each.

2- Feed hopper:- There is one feed hopper made of mild steel, having a prismatic cross section. The capacity of the hopper is $12690 \mathrm{~cm}^{3}$. The dimension of the hopper is $30 \mathrm{~cm} \times 16.2 \mathrm{~cm}$ for upper area, $30 \mathrm{~cm} \times 12 \mathrm{~cm}$ for lower area and $30 \mathrm{~cm}$ height, with $2.5 \mathrm{~kg}$ seed capacity of Rhodes grass.

3- Metering disc:- The metering disc was made of mild steel with cylindrical cells. The dimensions of the cells are $6 \mathrm{~mm}$ diameter and 10 mm deep. These dimensions allow for 5- 10 seeds can be accommodated if they are oriented on the major axis.

4- Transport wheels: The transport wheels are made of mild steel. The right wheel has a horizontal plate that bears the key that slide the precision metering mechanism. The diameter of the wheel is $35 \mathrm{~cm}$. The circumference of the wheel is designed to enable the planter discharge three times in one revolution of the wheels.

5- Furrow opening device: The two fixed furrow openers were $45 \mathrm{~mm}$ mild steel (angle bar) with a length of $130 \mathrm{~mm}$. The angle bar iron was fabricated to shoe type like structure to facilitate an easy cut through the soil and to collect more rain water when dropped to improve soil water retention, and operated at average walking speed of $(2.16 \mathrm{~km} / \mathrm{h})$. The distance between the furrow openers was $10 \mathrm{~cm}$.

6- Seed tube: The two seed tubes were made of plastic hollow pipe of 1.5 $\mathrm{cm}$ diameter and $60 \mathrm{~cm}$ length. Seeds picked from the hoppers pass 
through the hole at the metering mechanism to the seed tube which deposits the seeds into the opened furrow. The distance between the seed tubes was $10 \mathrm{~cm}$.

7- Furrow covering device: The furrow covering device was made of two pressing wheels of diameter $12 \mathrm{~cm}$. It was fastened with nut and bolt to the frame through a hole drilled on the frame.

The planter length was about $150 \mathrm{~cm}$ and the net weight was $22 \mathrm{~kg}$. The experimental unit area was $10 \mathrm{~m}^{2}(1.0 \times 10 \mathrm{~m})$ and the total projected area was $240 \mathrm{~m}^{2}$. The experiments consisted of 4 land slope treatments combined between the manually operated planting unit and hand labor planting under four slopes $(4.8,6.6,8.6$ and $10.4 \%)$ as illustrated in table (1):

Table (1): Applied treatments of the field experiments.

\begin{tabular}{|c|c|c|}
\hline \multirow{2}{*}{ Treatments } & \multirow{2}{*}{$\begin{array}{c}\text { Type of } \\
\text { planting }\end{array}$} & Land Slope (\%) \\
\hline \multirow{4}{*}{ P } & & 4.8 \\
\hline B & & 6.6 \\
\hline C & & 8.6 \\
\hline D & & 10.4 \\
\hline E & & 4.8 \\
\hline Hanting unit labor & planting & $\mathbf{6 . 6}$ \\
\cline { 1 - 1 } & & 8.6 \\
\hline F & & 10.4 \\
\hline H & & \\
\hline
\end{tabular}

Average meteorological measurements of rainfall $(\mathrm{mm})$ for the study area were obtained from Matrouh meteorological station through 2014/2015. Also the statistical analysis was carried out according to Steel and Torrie (1980).

\section{Laboratory tests:}

Mass of discharged seeds test: The hopper of the manualy operated planting unit was loaded with $100 \mathrm{~g}$ of Rhodes grass seeds. The planting unit was held to free the drive wheels were removed. A paint mark was made on each of the drive wheels to serve as reference points to count the number of revolutions when turned; and a plastic bag was placed on each of the discharge spouts to collect the seeds discharged. The drive wheels 
were rotated 50 times at low speed of $2.16 \mathrm{~km} / \mathrm{h}$ as would be obtained on the field. A stop clock was used to measure the time taken to complete the revolutions. The seeds in each bag were weighed on a balance and the procedure was repeated five times.

Damage Test: The test of seed damaged percentage was done with the machine held in a similar position to that described in calibration, but $500 \mathrm{~g}$ of seeds were loaded into each hopper. The wheels were rotated twenty times in turns and the time taken to complete the revolution was recorded by stop watch.

Uniformity of Seed Spacing: After seed germination by two weeks, the distances between successive seedlings within the row were determined for the planted land using a measuring tape.

\section{Field tests:}

\section{Field Efficiency (\%) and Field capacity (ha/h)}

The field capacity was determined by measuring the effective width of the machine using a measuring tape and the forward constant speed of planting operation. Investigation into the field efficiency and machine field capacity of the manually operated planting unit involved continuous observation and timing of each activity involved in the planting operation. The field efficiency and field capacity were therefore evaluated from equations by kepner et al, (1978):

Field efficiency $(\%)=($ Time for actual planting operation $/$ Total time taken $) \times 100$

Field Capacity $(\mathrm{ha} / \mathrm{h})=($ planting width $\mathrm{x}$ Forward speed $) / 1000 \times$ Field efficiency

\section{The soil moisture content, $(\%)$}

The soil moisture content, $\%$ of the projected trenching area was measured at surface soil depth $(0-15 \mathrm{~cm})$ and determined after 3 days of planting as a $\left(1^{\underline{\text { st}}}\right)$ record and after 40 days as $\left(2^{\underline{\mathbf{n d}}}\right)$ record after the planting date for each treatment, using the oven dry method.

\section{Seed germination and yield.}

Seed germination, $\%$ was determined and yield of two cuts of harvested periods after 3 and 6 months of planting Rhodes grass were determined for each treatment. Least significant difference (LSD) test was used for the comparison among treatments means, Steel and Torrie (1980). 


\section{RESULTS AND DISCUSSION}

\section{Average rainfall measurements for the studied area.}

The results in figure (2) showed the average rainfall $(\mathrm{mm})$ for projected area.

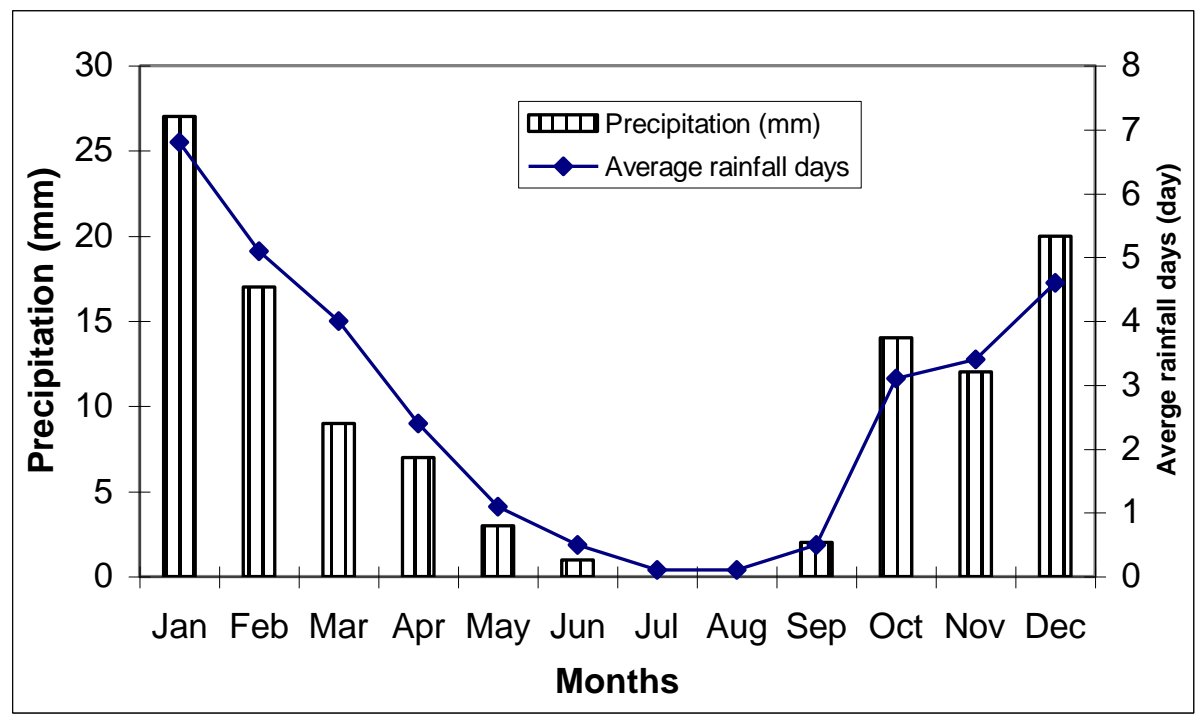

Fig. (2): The average rainfall (mm) for Marsa Matrouh 2014/2015.

The rainy season starting from September until the first of May, the other months gave none rainy periods. The highest average precipitation was observed in December by $42 \mathrm{~mm}$, while the lowest average precipitation was observed in June, July and August.

\section{Results of laboratory tests on manually operated planting unit:}

Table (2) reveals the results obtained from the calibration of the manually operated planting unit. It can be found that the average mass of seeds discharged from the hopper was $4.14 \mathrm{gm}$. This value was within the range of $\pm 7 \%$ recommended for optimum inter furrow variation by Mehta $e t$ al (1995). This was satisfactory performance and the design was such that the number of seeds metered out could be regulated by using adjustable metering device.

Table (2): Laboratory calibration of the manually operated planting unit

Calibration of the manually operating planting unit 


\begin{tabular}{ccc}
\hline Replications & Mass of discharged seeds (gm) & $\begin{array}{c}\text { Speed } \\
(\mathbf{r p m})\end{array}$ \\
\hline 1 & 3.98 & 27.8 \\
2 & 4.03 & 28 \\
3 & 4.12 & 28.6 \\
4 & 4.21 & 28.8 \\
5 & 4.35 & 29.1 \\
\hline Total Rate & 20.69 & 142.3 \\
\hline Mean & 4.138 & 28.46 \\
\hline
\end{tabular}

Table (3) shows the total average percentage of seed damage occurred during operation. It is observable that the average damage percentage was $2.66 \%$. The impressively low average value of seed damage percentage was probably due to the low speed at which the manually operated planting unit wheels were rotated during the laboratory tests.

Table (3): Percentage of seed damage during operation

\begin{tabular}{ccccc}
\hline \multicolumn{5}{c}{ Percentage of seed damage during operation } \\
\hline Replications & $\begin{array}{c}\text { Speed } \\
(\mathbf{r p m})\end{array}$ & $\begin{array}{c}\text { No. of } \\
\text { discharged } \\
\text { seeds }\end{array}$ & $\begin{array}{c}\text { No. of } \\
\text { seeds } \\
\text { damaged }\end{array}$ & $\begin{array}{c}\text { Damage } \\
\text { percentage } \\
(\%)\end{array}$ \\
\hline 1 & 28.8 & 66 & 0 & 0 \\
2 & 30.4 & 71 & 0 & 0 \\
3 & 32.5 & 74 & 1 & 1.35 \\
4 & 33.4 & 75 & 1 & 1.33 \\
5 & 35.7 & 77 & 2 & 2.59 \\
6 & 36.4 & 77 & 3 & 3.89 \\
7 & 37.5 & 78 & 3 & 3.84 \\
8 & 38.9 & 79 & 3 & 3.79 \\
9 & 39.2 & 81 & 4 & 4.9 \\
10 & 40.2 & 82 & 4 & 4.87 \\
Mean & 35.3 & 76 & 2.1 & 2.66 \\
\hline
\end{tabular}

Table (4) presents plant spacing measured in the laboratory and on the field determined after germination ( 2 weeks after planting). In the test conducted in the laboratory, the average seed spacing was $2.78 \mathrm{~cm}$ while in the field, the spacing obtained was lower with value of $2.74 \mathrm{~cm}$. the result of laboratory and field test shows uniformity in the plant spacing and equally gave close spacing to $2.8 \mathrm{~cm}$. However, the slight 
discrepancies in the results may be due to seed clogging and other operational factors.

Table (4): Laboratory and field determination for uniformity of seed spacing in row

\begin{tabular}{ccccc}
\hline \multicolumn{5}{c}{ Laboratory and field determination for uniformity of seed spacing in row } \\
\hline Replications & $\begin{array}{c}\text { Time } \\
\text { (sec) }\end{array}$ & $\begin{array}{c}\text { Speed } \\
\text { (m/sec) }\end{array}$ & $\begin{array}{c}\text { Laboratory } \\
\text { spacing (cm) }\end{array}$ & $\begin{array}{c}\text { Field } \\
\text { spacing (cm) }\end{array}$ \\
\hline 1 & 30 & 0.6 & 2.6 & 2.7 \\
2 & 30 & 0.6 & 2.8 & 2.8 \\
3 & 30 & 0.6 & 2.8 & 2.7 \\
4 & 30 & 0.6 & 2.8 & 2.7 \\
5 & 30 & 0.6 & 2.9 & 2.8 \\
Mean & 30 & 0.6 & 2.78 & 2.74 \\
\hline
\end{tabular}

\section{Results of field test on manually operated planting unit:}

Table (5) reveals the field efficiency and field capacity of the manually operated planting unit obtained from the field test. From the result, the field efficiency of the machine is $71.71 \%$ which implies good performance and fall within the range of values obtained by kepner $\boldsymbol{e t}$ al (1978), the result of the field capacity according to the table showed average value of $0.260 \mathrm{ha} / \mathrm{h}$.

Table (5): Field efficiency and effective field capacity of the manually operated planting unit.

\begin{tabular}{lc}
\hline \multicolumn{1}{c}{ Field Efficiency and Effective Field Capacity of the Planter } \\
\hline \multicolumn{1}{c}{ Activity } & Time /ha (min) \\
\hline Turning at field end & 12.4 \\
stones removal & 20.56 \\
Removal of seed tube clogs & 11.05 \\
Filling the seed hopper & 11.18 \\
Setting/adjustment & 10.3 \\
Actual planting & 145 \\
Total time & 210.49 \\
Field efficiency (\%) & 71.71 \\
Effective field capacity (ha/hr) & 0.26 \\
\hline
\end{tabular}

Effect of land slope on soil moisture content under different planting methods of the projected area.

The comparative effect of the planting methods on soil moisture content values of cultivated soil depth elucidated that manually operated planting unit had the highest soil moisture content values during growth season as shown in fig (3). The comparative effect of land slope on the soil 
moisture content values of cultivated soil depth during growth season revealed that $4.8 \%$ land slope had the highest soil moisture content values and ranked as $4.8 \%>6.6 \%>8.6 \%>10.4 \%$, that's attributed to the less runoff for the $4.8 \%$ land slope as compared to the other studied land slopes. Also, the obtained results indicated that soil moisture content values after 40 days of the planting date of Rhodes grass was higher than that obtained at the first record after 3 days under studied treatments.
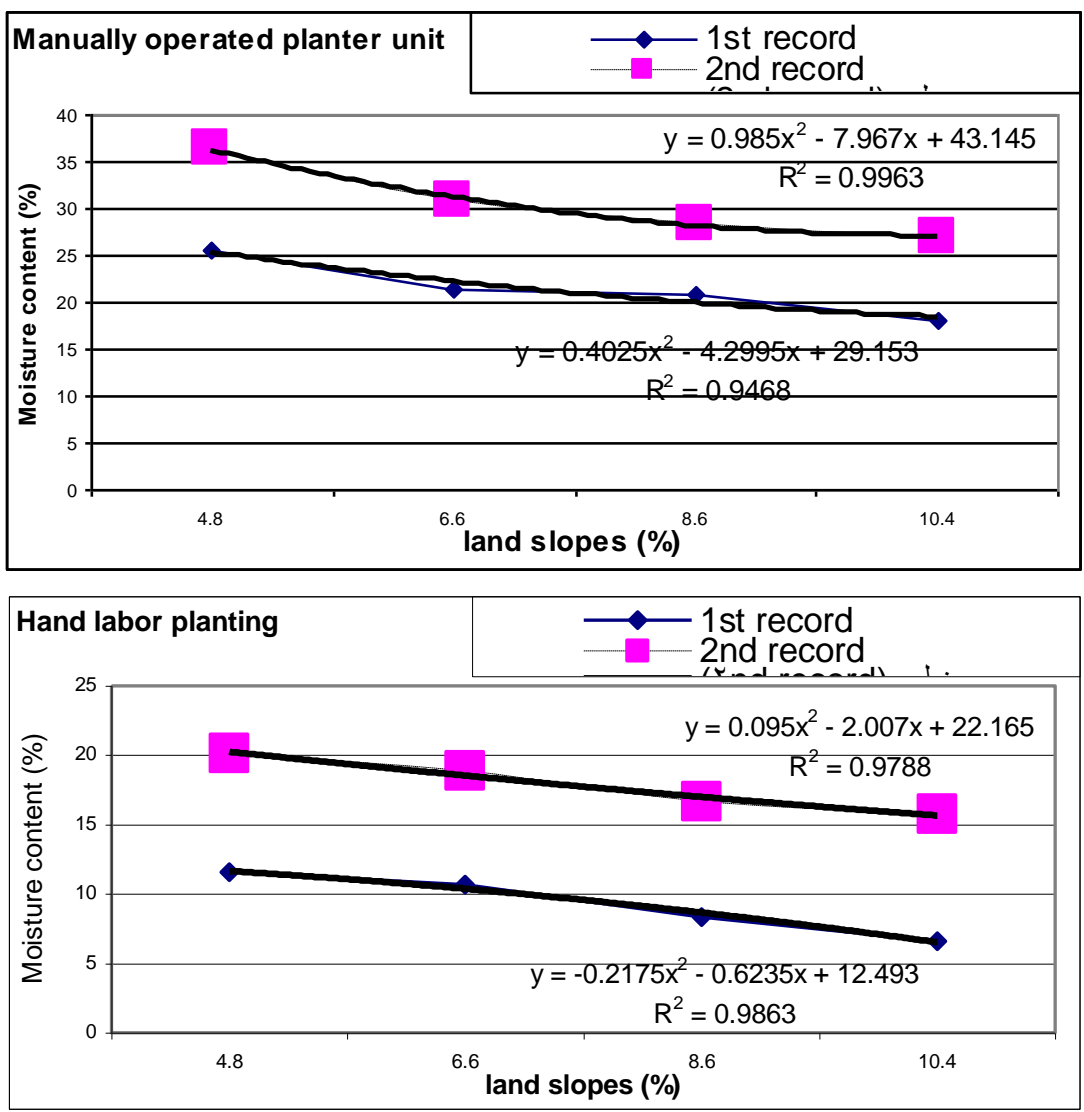

Fig. (2): Soil moisture content ( $Y$ ) after 3 and 40 days for different slopes (X). This trend could be due to the ability of soil trenching of the manually operated planting unit to conserve and keep water from rains, and also the continuity of rainfalls during 40 days from planting days during the growth season. Under studied treatments, the highest value of soil water content was 25.53 and $36.26 \%$ for the manually operated planting unit under $4.8 \%$ land slope treatment at the first record after 3 days and after 
40 days of the planting date, the same trend was similar to Hilary and Gary (1995), Nadia and Paiva (2007).

The effect of planting methods and land slope on seed germination percentage and biological yield.

The effect of planting methods and land slopes on seed germination values revealed that the manually operated planting unit had the highest values as shown in table (6).

Table (6): The effect of the planting methods and land slope on seed germination percentage and biological yield.

\begin{tabular}{c|c|c}
\hline Treatment & Seed Germination (\%) & Biological Yield (Mg/ha) \\
\hline A & 98.8 & 92.447 \\
B & 95.0 & 84.792 \\
C & 93.7 & 81.733 \\
D & 93.4 & 76.528 \\
\hline E & 90.3 & 63.671 \\
F & 85.4 & 63.059 \\
G & 85.4 & 57.550 \\
H & 81.0 & 48.059 \\
\hline LSD 0.05 & $\mathbf{2 . 9 2}$ & $\mathbf{1 . 6 0 8}$ \\
\hline
\end{tabular}

The seed germination percentage values of Rhodes grass showed that the land slope of $4.8 \%$ had the highest values and ranked as $4.8 \%>6.6 \%>$ $8.6 \%>10.4 \%$. The obtained results in table (6) revealed that the seed germination percentage values ranged between 90.3 to $98.8 \%, 85.4$ to $95.0 \%, 85.4$ to $93.7 \%$ and 81.0 to $93.4 \%$ for $4.8,6.6,8.6$ and $10.4 \%$ land slope for both cultivation methods and land slope treatments, respectively. The seed germination values were appeared significantly affect with $\mathrm{LSD}_{0.5}$ values was 2.92. On the other hand, the effect of planting methods and land slopes on yield values for 2 harvested times, revealed that the manually operated planting unit had the highest values as compared with hand labor planting. The total biological yield values under different treatments were demonstrated significant effect as clarified in table (6). The obtained results showed that the land slope of $4.8 \%$ had the highest yield values. The effect of land slopes on the yield values were ranked as $4.8>6.6>8.6$ and $>10.4 \%$. The obtained results 
revealed that the total biological yield values varied between 63.671 to $92.447 \mathrm{Mg} / \mathrm{ha}, 63.059$ to $84.792 \mathrm{Mg} / \mathrm{ha}, 57.550$ to $81.733 \mathrm{Mg} / \mathrm{ha}$ and 48.059 to $76.528 \mathrm{Mg} / \mathrm{ha}$ under land slopes of 4.8, 6.6, 8.6 and $10.4 \%$, respectively. Furthermore, the total biological yield values appeared significant effect with $\mathrm{LSD}_{0.5}$ value of $1.608 \mathrm{Mg} / \mathrm{ha}$. Under the studied treatments, the obtained results in table (6) showed that the highest biological yield value was $92.447 \mathrm{Mg} /$ ha by using the manually operated planting unit with land slope of $4.8 \%$. This might be due to the effect of conserving more moisture on the soil profile which could be considered suitable to the optimum levels of growth as compared to the other planting methods consequently, seedling emergence, vegetation growth and crop yield were relatively high. At the same treatments, the lowest biological yield value was $48.059 \mathrm{Mg} / \mathrm{ha}$ and found by using hand labor planting method with land slope of $10.4 \%$ treatment.

\section{CONCLUSION}

A simply manually operated planting unit was evaluated to cultivate Rhodes grass on sloping lands by operating the seeds directly into the soil. Two different criteria of planting methods were used as manually operated planting unit and hand labor planting for evaluating soil moisture content, field capacity, seed germination and yield. The soil moisture content values of cultivated soil depth elucidated that the manually operated planting unit had the highest soil moisture content values during growth season and can be ranked as $4.8 \%>6.6 \%>8.6 \%>$ $10.4 \%$ land slopes. This result might be attributed to the $4.8 \%$ land slope make the soil surface stable, consequently less runoff and more water collection from rainfall was achieved. Also, the soil moisture content values after 40 days from planting of Rhodes grass was higher than that after 3 days. This trend could be attributed to the ability of soil to conserve and keep water, and also the duration of rainfalls during 40 days from planting through the growth season. The highest value of soil water content was 25.53 and $36.26 \%$ for manually operated planting unit under $4.8 \%$ land slope treatment after 3 days and after 40 days of the planting date, respectively. Concerning the field capacity, the obtained data showed that the maximum field capacity value was $0.52 \mathrm{ha} / \mathrm{h}$ for the 
manually operated planting unit under land slope of $4.8 \%$, while, the minimum value was $0.20 \mathrm{ha} / \mathrm{h}$ for hand labor planting method under land slope of $10.4 \%$. The satisfactory results of the manually operated planting unit was attributed to its maneuverability and also more soil stability for the land slope of $4.8 \%$ as compared to the other land slopes, which facilitate the planting operation. Seed germination values revealed that the manually operated planting unit had the highest values as compared with hand labor planting method. This trend might be attributed to the usage of manually operated planting unit increased the soil moisture content through the growing season. Also, the seed germination values showed that the land slope of $4.8 \%$ had the highest values and ranked as $4.8 \%$ > $6.6 \%>8.6 \%>10.4 \%$. The obtained results revealed that, seed germination percentage values ranged between 90.3 to $98.8 \%, 85.4$ to $95.0 \%, 85.4$ to $93.7 \%$ and 81.0 to $93.4 \%$ for $4.8,6.6,8.6$ and $10.4 \%$ land slope, respectively. On the other hand, the yield values revealed that the manually operated planting unit had the highest record. that's due to the ability to collect and conserve more moisture through the soil profile during growing season. Also, the land slope of $4.8 \%$ had the highest yield values. The highest biological yield value was $92.447 \mathrm{Mg} / \mathrm{ha}$ by using manually operated planting unit with land slope of $4.8 \%$. This might be due to the effect of conserving more moisture on the soil profile which could be considered suitable to the optimum levels of growth consequently, seedling emergence, vegetation growth and crop yield were relatively high. At the same treatments, the lowest biological yield value was $48.059 \mathrm{Mg} / \mathrm{ha}$ by using hand labor planting method with land slope of $10.4 \%$ treatment.

\section{REFERENCES}

Adekoya, L. O., and W. F. Buchele.(1987). A precision punch planter for use in tilled and untilled soils. J. Agric. Eng. Res. 37:171-8.

Adisa A.F. (1980). Design and Construction of a Manualy Operated Planter. Unpublished B.Eng. Thesis, Ahmadu Bello University, Zaria, Nigeria.

Bamgboye, A.I and Mofolasayo, A.S (2006). "Performance Evaluation of a Two-Row Okra Planter”. Agricultural Engineering 
International: the CIGR Ejamal. Manuscript PM 06002. Vol.viii. July.

Braide F.G. and S.M. Njidda. (1989). Design and Construction of a Combined Jab Planter, Proceedings of Nigerian Society of Agricultural Engineers (13).

Hilary F. R.and F. Gary (1995). Microcatchment Water harvesting for agricultural production: Part I: Physical and technical considerations. J. Ranglands, 17 (3): 72-78.

Kachman, S. D., and J. A. Smith. (1995). Alternative measures of accuracy in plant spacing for planters using single seed metering. Transactions of the ASAE 38(2):379-387.

Kepner, R.A; Bainer, R. and Barger, E.L. (1978). Principles of farm machinery. 3rd Edition. West port. G; AVI publishing company Inc.

Klute, A. (ed.) (1986). Methods of Soil Analysis. Part 1. Physical and Minerological Properties. Am. Soc. Agron. Inc., Agronomy Series 9. USA. 1173 pp.

Mehta, M.L.; Verma, S. R. Misra, S.K. and Sharma, V.K. (1995). Testing and Evaluation of Agricultural Machinery. National Agricultural Technology Information Centre, India. Pp 68 - 79.

Molin, J.P. and Dagostine, V. (1996). Development of a rolling punch planter for stony soil conditions" Agricultural mechanization in Asia, Africa and Latin America. Vol.27, No3, pp17-19.

Morrison Jr., J. E., and R. R. Allen. (1987). Planter and drill requirements for soil with surface residues. Paper presented at the Southern Region No-tillage Conf. on Conservation Tillage, MiscPub-MP-Agri-Exp-Stn (1636): 44-58. College Station.

Nadia, I. and M. Pavia (2007). Rain water harvesting technologies for Small scale rainfed agriculture in arid and semi-arid areas, Integrated water resources management for improved rural livelihoods, CGIAR challenge program on water and food.

Robert, G.; H. David and P. Robert (2009). Equipment Considerations for No-till Soybean Seeding. Virginia Cooperative Extension Programs. publication 442-456.

Rogers, B., and R. Baron. (1987). Cereal punch seeder; true zero till seeding. ASAE Paper No. 87-1615. St. Joseph, Mich.: ASAE. 
Rolando, P.J., Delaraga, L.V., Alegato, O.R. (2011). Development of a manually operated Disc- type corn seeder. Northwestern University, Laoag City 2900, Philippines, Mariano Marcos State University, Batac, Ilocos Norte 2906, Philippines.

Shaw, L. N., and K. H. Kromer. (1989). A punch planter for vegetables on plastic mulch covered beds. In Proc. 11th Intnl. Congress Agric. Engineering, Vol. 3, Agricultural Mechanization, 1711-1715. Dublin Ireland. Rotterdam, The Netherlands: A. A. Balkema.

Srivastava, A. K., and M. E. Anibal. (1981). A punch planter for conservation tillage. ASAE Paper No. 81-1020. St. Joseph, Mich.: ASAE.

Steel, R. G. D., and J. H. Torrie. (1980). Principles and Procedures of Statistics. McGraw-Hill, New York.

Wohab, M.A. (2003). Design and development of a power tiller operated minimum tillage seeder. MS thesis. Department of Farm Power and Machinery, Bangladesh Agricultural University, Mymensingh, Bangladesh.

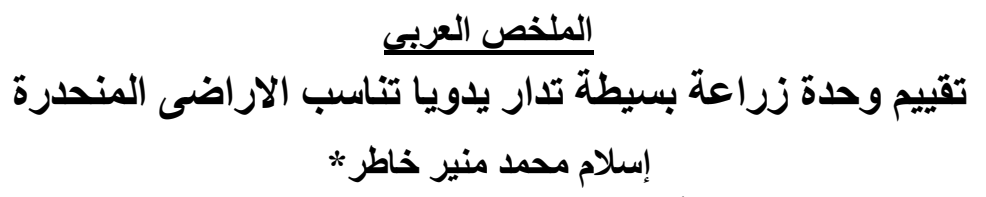

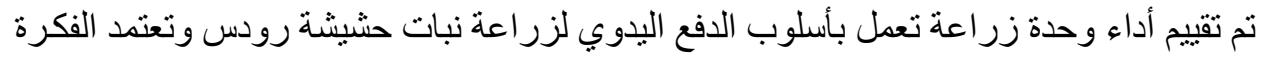

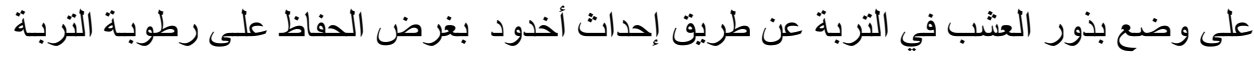

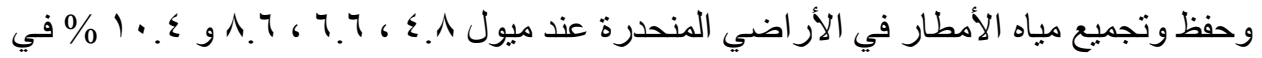

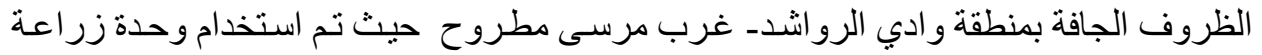

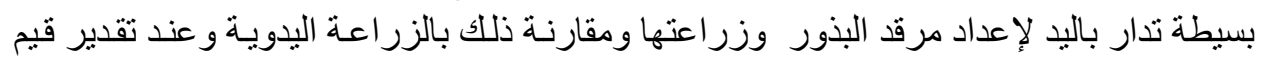

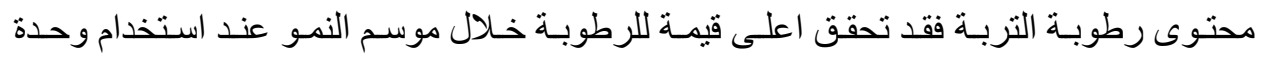

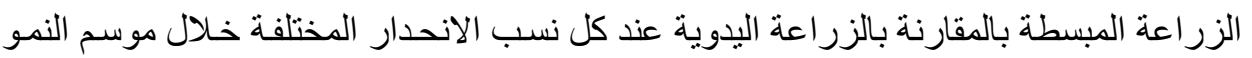

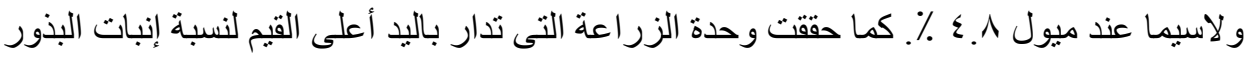

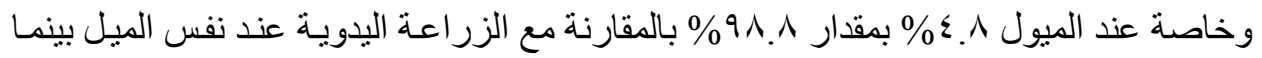

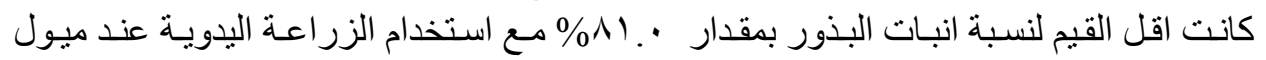

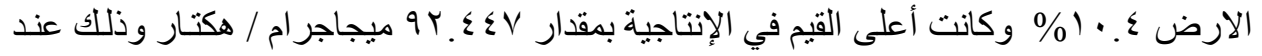

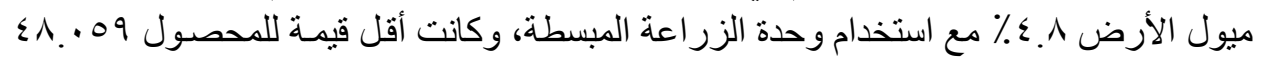

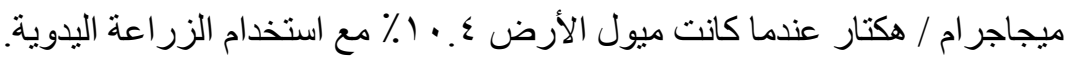

*قسم صيانة الاراضى- مركز بحوث الصحراء- القاهرة- مصر. 